\title{
SOKRATES A TÉLAUGES - AISCHINOVA SOKRATIKA MEDZI PLATONIZMOM A KYNIZMOM
}

FRANTIŠEK ŠKVRNDA, Katedra medzinárodných politických vzt’ahov Ekonomickej univerzity v Bratislave, Bratislava, SR

\begin{abstract}
ŠKVRNDA, F.: Socrates and Telauges - Aeschines' Socratica between Platonism and Cynicism

FILOZOFIA, 74, 2019, No. 1, pp. $40-51$

Following paper offers a new interpretation of the fragments from Aeschines' dialogue Telauges. The introduction briefly evaluates the literary sources of Aeschines' fragments and problems related to their authorship and authenticity. In the first part we scrutinize ancient testimonies about general philosophical and rhetorical features of Aeschines' dialogues. In the next parts we interpret all extant fragments from the dialogue Telauges and identify its putative pythagorean background. We propose that the main theme of the dialogue was the question of the care of the self, articulated on the background of philosopher's material welfare and philanthropy. We conclude that Telauges probably reflected the consequences that chanced upon the first generation of Socratics immediately after Socrates' trial and that Aeschines' Socratica stands in the middle between Platonism and Cynicism.
\end{abstract}

Keywords: Aeschines - Telauges - Socrates - Pythagoreanism - Philanthropy Therapy

Úvod. Dielo Aischina zo Sféttu je pre nás nenávratne stratené, $\mathrm{z}$ jeho siedmich dialógov sa zachovali iba fragmenty. ${ }^{1}$ Bádatelia nemajú jasno ani $v$ tom, kol'ko zlomkov možno pričítat' Aischinovi. Dittmar zaradil do svojej zbierky len pätdesiattri zlomkov (1912, 266 - 296). Giannantoni, s ktorého edíciou v štúdii pracujeme, $\mathrm{k}$ nim pridal aj všetky svedectvá o Aischinovom živote, a takisto aj jeho listy, čím celkovo nazhromaždil stotri zlomkov (1990, 593 - 629). V poslednom čase sa však vyskytujú hlasy, že ani tento počet nemusí byt' konečný, pretože Aischinovo myslenie môže byt' implicitne prítomné vo viacerých textoch, ktoré Giannantoni do svojej zbierky nezahrnul (Pentassuglio 2017).

Ak sa pozrieme na Giannantoniho edíciu detailnejšie, zistíme, že z vyše sto aischinovských zlomkov takmer jednu pätinu predstavujú priame citácie z

\footnotetext{
${ }^{1}$ K otázke autentickosti Aischinových dialógov, ktoré boli spochybňované už v antike, pozri bližšie štúdiu Beall (2001). Autor v nej dochádza k záveru, že pravých Aischinových dialógov bolo sedem, zvyšné, takzvané „akefalické“, boli dielom Pasifónta z Eretrie.
} 
Aischinových dialógov. ${ }^{2}$ Situácia sa však komplikuje, pretože ani jeden z týchto priamych citátov nemá takpovediac žiadnu filozofickú hodnotu. Ide len o izolované výrazy, slovné spojenia alebo štylisticky zaujímavé vety, ktoré si zapisovali neskorší antickí gramatici pre ich osobitost' či zvukomalebnost'. Väčšina zo zvyšných fragmentov síce má filozofický charakter, problémom je však ich proveniencia. Pochádzajú prevažne od autorov druhej sofistiky (Flavios Filostratos, Aelios Aristeides, Maximos z Tyru, Dion z Prusy) a jej širšieho intelektuálneho prostredia (Pollux, Plutarchos, Diogenes Laertský, Aténaios, Galenos). Referáty, ktoré sa vyznačujú filozoficky najpregnantnejším obsahom, pochádzajú najmä od Aelia Aristeida a Maxima z Tyru, ktorí vo svojich rečníckych deklamáciách imitujú Aischina a štylizujú sa do pozície akýchsi jeho diskusných partnerov, pričom do diskusie s Aischinom neraz zapájajú aj Platóna, iných sokratovcov, či dokonca samého Sokrata. Parafrázuje Maximos vo svojej XXXVIII. reči $(O$ tom, či sa človek môže stat' prostredníctvom božského údelu dobrým) Aischina len $\mathrm{v}$ štvrtom paragrafe, ako sa nazdáva Giannantoni, alebo je celá reč (7 paragrafov) prestúpená odkazmi a aforizmami, ktoré sa viažu k Aischinovmu dialógu Alkibiades? Kde viest' deliacu čiaru medzi Maximovými (Aeliovými) vlastnými myšlienkami a myšlienkami prevzatými z Aischinových dialógov, ked' ich nemôžeme porovnat's originálom? Tieto otázky bezpochyby st’ažujú prácu historikom filozofie, ktorí sa usilujú odhalit' povahu Aischinovej sokratiky a definovat' jeho filozofické postoje. Aischinove myšlienky sú totiž natol'ko zrastené s myšlienkami autorov, čo ich prezentujú, že je takmer nemožné určit' medzi nimi deliacu čiaru.

V predkladanej štúdii sa preto pokúsime minimalizovat' hermeneutické problémy spojené s interpretovaním Aischinovho myslenia a zvolíme si taký postup, ktorý nám umožní zachytit' autentické Aischinove myšlienky a úvahy bez neskorších kontaminácií a interpolácií. $Z$ tohto dôvodu sa sústredíme výhradne na Aischinov dialóg Télauges, $\mathrm{z}$ ktorého sa zachovalo len osem zlomkov. Obsah tohto dialógu sme sa rozhodli rekonštruovat' prostredníctvom interpretačného pravidla kontextuálnej koherencie, teda vsadit' ho do celkového intelektuálneho prostredia, v ktorom Aischinés tvoril a žil, a na ktoré zlomky priamo odkazujú.

Aischinova sokratika - všeobecné charakteristiky. Kým prejdeme k analýze zlomkov Aischinovho Télauga, pokladáme za potrebné zhodnotit' správy antických autorov o Aischinovom mieste v dejinách antickej filozofie. Hoci niektorí moderní bádatelia označujú Aischina za „menšieho z menších sokratovcov“" (Mársico 2018, 202), z antických správ o Aischinových dielach vyplýva presný opak.

\footnotetext{
${ }^{2}$ Celkovo dvadsat'tri zlomkov. Porov. [SSR VI A $12=$ A 94, A $43-45,57,65,69,76-77,79$, $82,88,92,95-100]$.
} 
Z formálneho hl'adiska predstavovali Aischinove dialógy originálny typ sokratovskej literatúry, ktorý bol na jednej úrovni s dielami Xenofóna, Platóna či Antisthena. V Hermogenovej príručke o štýloch nachádzame nasledovné zhodnotenie Aischinovho slohu (Hermog., De ideis II 12,2 = [SSR VI A 20]): „Zdá sa, že o kol'ko Xenofón prevyšuje jednoduchost'ou Platóna, o tol'ko Aischinés prevyšuje jemnost’ou Xenofóna.”3

Výraz ,jemnejšsi“ by nás nemal zvádzat' k tomu, aby sme v Aischinovom diele videli naivnú a povrchnú filozofickú literatúru. „Jemnost"“ ( $\lambda \varepsilon \pi \tau$ tó $\left.\eta_{\varsigma}\right)$ sa totiž zvykla spájat' s takým typom reči, ktorá je $\mathrm{z}$ argumentačného hl'adiska detailne prepracovaná a preto prijatel'ná pre poslucháča. ${ }^{4}$ Takéto ohodnotenie Aischinovho slohu môže zachytávat' základnú črtu Aischinovho štýlu, ktorou je mimoriadna presvedčivost'.

Aischinés musel figurovat' ako významný autor sokratovských dialógov už $\mathrm{v}$ štvrtom storočí pred Kristom. Aristoteles hodnotí presvedčivost' Aischinových diel týmito slovami (Aristoteles, Rhet. 1417 b1 $=$ [SSR VI A 92]): „Okrem toho musí tvoja reč čerpat' aj z l'udských emócií. Dosiahneš to tak, že budeš opisovat' ich následky, ktoré poslucháči dobre poznajú. Dôležitý je aj opis charakteristických vlastností toho či onoho človeka. Napríklad... čo hovorí Aischinés o Kratylovi: Hlasno zasipel a zamával rukami. Toto je presvedčivé, pretože niečo známe sa stáva symbolom pre to, čo je neznáme."

Pre Aristotela je Aischinov spôsob presviedčania príkladom sokratovského $\dot{\varepsilon} \pi \alpha \gamma \omega \gamma \eta ́$, teda induktívneho úsudku vychádzajúceho z analógie. Zaujímavé je najmä Aristotelovo vysvetlenie, prečo je Aischinés taký presvedčivý - jeho argumenty analógiou sa zakladajú na tom, že jedna čast' analógie je všeobecne známa a prijímaná, zatial' čo druhá je neznáma a má sa tou prvou dokazovat' a potvrdit'. Aischinov prejav tak predstavuje pre Aristotela vzor sokratovskej metódy dokazovania, ktorá operuje prostredníctvom l'udských emócií.

Významné svedectvo o Aischinovom podmanivom štýle argumentovania podáva aj zlomok Timóna z Fliuntu (320 - 235 pred Kristom), autora filozofickej satiry Škul'aví ( $\Sigma \dot{i} \lambda \lambda \mathrm{\jmath})$. Timón vyjadruje Aischinovi uznanie vel'mi špecifickým, no pre neho typickým spôsobom (Diog. Laert., Vit. II 55 a 62 = [SSR VI A 13]): „Slabé sú tie dva či tri či zopár viac spisov Xenofónových a sila Aischina, nie neschopná pri súdnych sporoch.“

Aischina Timón považuje za presvedčivého súdneho rečníka, čo korešponduje s inými doxografickými správami o tom, že Aischinés spolu so Sokratom ako prvý vyučoval rétoriku v Aténach (Diog. Laert. Vit. II 20). Okrem Aristotela a Timóna sa

\footnotetext{
${ }^{3}$ Preklady Aischinových zlomkov preberáme od A. Kalaša s miernymi úpravami.

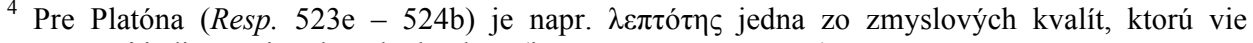

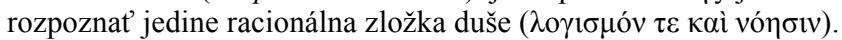


nám zachovalo významné svedectvo Panaitia z Rhodu (185 - 110 pred Kristom), ktorý pokladal Aischinove dialógy spolu s tými Platónovými, Xenofónovými a Antisthenovými za pravé, teda vzorové diela sokratovskej literatúry (Diog. Laert., Vit. II $64=$ [SSR VI A 27/I H 17]). Neskorší antickí gramatici, akými sú vyššie uvedený Hermogenes či anonymný autor Rétoriky, ${ }^{5}$ hodnotia Aischinov štýl dokonca vyššie ako Platónov. Väčšina d'alších autorov sa však zhodne na Panaitiovom súde a Aischina zarad’uje na úroveň klasických sokratovcov Platóna, Xenofóna a Antisthena. ${ }^{6}$

Zo svedectiev o Aischinovom mieste v dejinách sokratiky môžeme vyvodit' niekol'ko plauzibilných záverov. Podmanivost' Sokratovej rečníckej schopnosti je zachytená nielen Xenofónom a Platónom, ale najmä Aischinom, ktorého tradícia pokladá za najbližšieho a najvernejšieho Sokratovho spoločníka. ${ }^{7}$ Aischinés pracuje s postavou Sokrata trochu inak ako Xenofón a Platón. Zatial' čo prvý referuje o Sokratovej bezúhonnosti a cnostnom živote, druhý ho necháva rozvíjat' komplexné metafyzické úvahy a zobrazuje ho ako náruživého hl'adača definícií. ${ }^{8}$ Aischinove dialógy boli zrejme väčšmi prakticky orientované ako tie Platónove a väčšmi argumentačne prepracované ako tie Xenofónove. Ako príklady tém, ktoré riešil Aischinés vo svojich dialógoch, by sme mohli uviest' napr. Alkibiadov problém so ženami a pitím vína (Axiochos), ${ }^{9}$ Xenofónov problém manželskej lásky $\mathrm{k}$ jeho žene (Aspasia), alebo spôsob, akým sa Sokratés usiloval pripravovat' Alkibiada na kariéru spravodlivého politika (Alkibiades). Zdá sa, že Aischinove práce predstavovali príklady starostlivosti o druhých $(\theta \varepsilon \rho \alpha \pi \varepsilon i ́ \alpha)$, nadobúdajúcej formu praktickej pomoci, ktorú filozof preukazuje druhým l'ud'om. ${ }^{10}$

\footnotetext{
${ }^{5}$ Porov. Giannantoni (1990, 603).

${ }^{6}$ Tak napr. Longinos hovorí o Platónovi, Xenofónovi, Aischinovi a Antisthenovi [SSR VI A 34], spomínaný Anonym o Aischinovi, Herodotovi, Isokratovi, Lysiovi a Démosthenovi [SSR VI A 35]. Frýnichos Aischina zarad'uje na úroveň Platóna, Démostena a deviatich rečníkov, d’alej Túkydida, Xenofóna, Kritia, Antisthena, Aristofana, Aischyla, Sofokla a Euripida [SSR VI A 33]. Demetrios [SSR VI A 32] a Michael Psellos [SSR VI A 36] ho kladú na roveň Platónovi.

${ }^{7} \mathrm{O}$ tom, že antickí doxografi pokladali Aischina za najvernejšieho Sokratovho žiaka, svedčí tiež anekdota, podl'a ktorej mal údajne Aischines od Xantipy obdržat' po Sokratovej smrti jeho vlastné dialógy (Diog. Laert., Vitae II 60). Porovnaj tiež jedinú zmienku o Aischinovi u Platóna, kde sa spomína ako člen najvnútornejšieho okruhu Sokratových priatel'ov [SSR VI A 5].

8 Pozri bližšie Brisson (2018, 238 - 239), ktorý bližšie špecifikuje rozdielnost' medzi Xenofónovým a Platónovým Sokratom. Väčšmi analytický výklad Sokratovej metafyziky, ktorý vychádza z aporetických Platónových dialógov, pozri v Prior (2013).

9 Platón zobrazuje Alkibiada taktiež ako silného pijana (Symp. 218a - 220e), ale túto problematiku s ním Sokrates nikde nerieši.

${ }^{10} \mathrm{~K}$ otázke terapeutického efektu Aischinových diel pozri interdisciplinárne zameranú štúdiu Lampe (2010), ktorá sa zameriava najmä na úlohu vášne a lásky (̇̉ $\rho \varsigma)$ ako hlavnej kategórie, cez ktorú Sokrates pôsobí na druhých. K Sokratovej forme terapie v Platónovom dialógu Charmidés pozri bližšie Suvák (2018).
} 
Aischinove diela tak mohli mat' tú črtu, že boli protreptické, pričom s istou mierou pravdepodobnosti môžeme dokonca tvrdit', že zachytávali myšlienky a postoje historického Sokrata, ktoré Aischinés nielenže verne zapisoval, ale aj majstrovsky upravoval po štylistickej stránke.

Télauges - dramatis personae. Prejdime teraz k Aischinovmu dialógu Télauges, o ktorom sa nám zachovalo celkovo len osem svedectiev [SSR VI A 83 - 90]. Začneme dramatickou kompozíciou, ktorú sme schopní na základe zachovaných zlomkov a kontextu rekonštruovat'. V dialógu explicitne vystupovali Sokrates, Hermogenes a Télauges, implicitne možno sám Aischinés a Kritobulos.

Meno Télauges je v gréckej literatúre také zriedkavé, že poznáme prakticky len jednu postavu s týmto menom, ktorá žila pred tretím storočím pred Kristom: je ňou legendárny Pytagorov syn, učitel' predsokratovcov Empedokla z Akragantu a Xenofana z Kolofónu (Diog. Laert., Vit. I 15). Podl'a niektorých antických autorov Télauges - podobne ako Sokrates - nič nenapísal, no po svojom otcovi zdedil viaceré spisy, ktoré predtým uchovávala jeho staršia sestra Damóna, ktorá ich zase získala od svojej matky a Pytagorovej ženy Theanó. ${ }^{11}$ Podla iných autorov Télauges napísal diela $O$ Tetrakyse a Posvätná reč alebo o bohoch ${ }^{12}$ Hoci sa žiadne zlomky od Télauga - ak vôbec nejaké existovali - nezachovali, je dôležité vnímat' ho očami antických filozofov ako nástupcu autentickej pytagorovskej tradície, v ktorej zvyknú niektorí bádatelia vidiet' rozkol medzi matematikmi a akuzmatikmi. ${ }^{13}$

Télauges je v Aischinovom dialógu vyobrazený ako spoločník Hermogena (Proklos, In Plat. Cratyl. $21=[S S R$ VI A 83]): „Pretože Hermogenes je zosmiešňovaný u Aischina za to, že ho kazia peniaze; nezaujímalo ho, že prehliada Télauga, svojho oblúbeného spoločníka, o ktorého nebolo postarané.“

Niektorí bádatelia sa nazdávajú, že z chronologického hl'adiska je dej Télauga historicky nemožný. ${ }^{14}$ Dejová línia dialógu sa na prvý pohl'ad skutočne javí ako t’ažko udržatel'ná: Pytagorov údajný syn pôsobil v Aténach ako približne 80-ročný

${ }^{11}$ Porov. bližšie Rowett $(2014,123)$

${ }^{12}$ Télaugove spisy a odkazy na ich antické zdroje (Suidas) pozri v Dittmar $(1912,215)$.

${ }^{13}$ Zhrnutie diskusie k problematike matematikov $v$ s. akuzmatikov pozri v Thom $(2013,83-87)$.

Tento autor sa usiluje zaujat' strednú pozíciu, ktorá na jednej strane neredukuje pravý pytagoreizmus na rituálne dodržiavanie akuziem (Burkert) ani na „sekulárne“ matematické skúmanie kozmu (Zhmud).

${ }^{14}$ K chronológii pozri bližšie Nails $(2002,273$ - 274). Nailsová však prehliada takú možnost' čítania zlomku [SSR VI a 84] (uvedený nižšie), v ktorej Kritobulos vôbec nefiguruje ako postava dialógu. Takéto čítanie je nielen možné, ale vzhl’adom na pomerne časté „alegorické“ výklady postáv sokratovskej literatúry (porov. Diog. Laert., Vitae II 60, III 34, 36) aj pravdepodobné. Napokon možno uvažovat' aj nad tým, či dialóg nebol - tak ako niektoré Platónove dialógy vrstvený metanaratívne a či nenadobúdal formu nepriamej reči, v ktorej Aischines a Kritobulos počúvajú príbeh o Télaugovi od niekoho iného, kto ho reálne zažil alebo vypočul (napr. od Sokrata). 
(ak nie 90-ročný) spoločník azda 20-ročného Hermogena. ${ }^{15}$ Môžeme hypoteticky uvažovat' nad tým, že pre kultúru antického Grécka nebolo nič nezvyčajné, ak mali mladí bohatí muži na starosti starých hostinných priatel'ov svojich otcov a príbuzných. Ako dokazuje príbeh o Periklovi a Anaxagorovi, sú to napokon práve starnúci filozofi, ktorí potrebujú starostlivost' svojich mladších priatel'ov a nasledovníkov: Anaxagoras sa rozhodol v pokročilom veku ( $\gamma \eta \rho \alpha i o ́ v)$ zomriet', lebo ho každý, vrátane Perikla, prehliadal. Perikla to vel'mi rozrušilo a pokúšal sa Anaxagora odhovorit' od jeho úmyslu, pretože ho potreboval ako svojho politického radcu. Anaxagoras, ktorý sa už zahalený do plášt’a pripravoval zomriet' a zdržiaval sa jedla, sa zrazu odokryl a odpovedal mu: „Perikles, tí, čo potrebujú lampu, musia do nej prilievat' olej!“ (Plutarch., Pericles 16)

Vzt'ah Hermogena a Télauga tak mohol byt' analogický vzt’ahu Perikla a Anaxagora - Hermogenes sa nestará o svojho vychovávatel'a a učitel'a, z ktorého má inak vel'ký prospech, a práve to je predmetom Aischinovho výsmechu - prvok komickosti je napokon zjavný aj v príbehu o Anaxagorovi. Takúto hypotézu, ktorá sa pohybuje na hrane chronologickej udržatel'nosti (Télauges ako Xenofanov učitel'!), však treba prijímat' opatrne. Pravdu totiž môžu mat' aj tí autori, ktorí sa nazdávajú, že sokratika ako literárny žáner sa vyznačovala fiktívnym dejom a jej kardinálnym znakom nebola historicita (Suvák 2006, 16; Kalaš, Suvák 2013, 310; Mársico 2018,213). Sokrates a Hermogenes tak pokojne môžu kráčat' popri bájnom Télaugovi, Pytagorovom synovi, ktorý azda ani nikdy neexistoval.

Pytagorovské pozadie Télauga. Zdá sa, že dialóg Télauges sa dotýkal problematiky pytagorovskej filozofie. Jeden z ôsmich zlomkov k Télaugovi (ktorý Giannantoni zaradil k Aischinovým zlomkom napriek tomu, že explicitne neobsahuje jeho meno) znie takto (Plutarch., De curios. 516c = [SSR VI a 90]): „Sokrates chodil stále dokola a nevedel si dat' rady s Pytagorovou presvedčivou rečou.“

Postava Pytagora privádzala Sokrata nejakým spôsobom do apórie, čo môže indikovat' situáciu nie nepodobnú Platónovmu Parmenidovi, kde starší predsokratovec vystupuje voči Sokratovi ako autorita, ktorá ho privádza do bezradnej situácie. Ak odhliadneme od dvoch pasáží z Platónovej Ústavy (530d, $600 \mathrm{~b}$ ), tak ide o ojedinelé miesto v celej sokratike, kde sa Sokrates zamýšl’a priamo nad Pytagorovými myšlienkami, a kde vystupuje v netradičnej pozícii bezradnosti, do ktorej ho dostal iný filozof.

Pytagoreizmus presvitá aj z d’alšieho, filozoficky najpregnantnejšieho zlomku

\footnotetext{
${ }^{15}$ Nie je jasné, či ide o toho istého Hermogena z Alopék, ktorý vystupuje u Xenofóna a Platóna, ale ked’že ide o jedného z bližších Sokratových priatel’ov, tak sa vo všeobecnosti predpokladá, že táto postava vystupovala aj v Aischinovom Télaugovi. Nailsová sa usiluje stlačit' dátum narodenia Hermogena asi do desat'ročia 440 pred Kristom, no vzhl'adom na absenciu akýchkolvek presnejších údajov môžeme dátum jeho narodenia predpokladat' približne v rozmedzí rokov 455 435 pred Kristom.
} 
z Télauga, ktorý sa môže pochválit' dobrou provenienciou - pochádza totiž od žiaka stoika Kratéta z Mallu, jedného z prvých profesorov Pergamskej knižnice za jej naj-

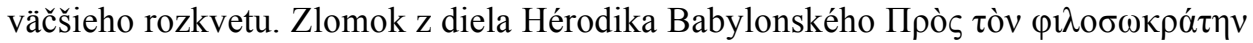
(2. stor. pred Kristom) u Aténaia (V 220A = [SSR VI A 84]) znie takto: „Väčšina filozofov zvykne hanit' autorov komédií, ako napríklad sokratovec Aischinés v Télaugovi zosmiešňuje Kritónovho syna Kritobula pre nevzdelanost' a nedostatočnú osobnú hygienu. Télauges údajne platil za svoj plášt' každý deň pol obola nejakému valchárovi. Vel'mi smiešne ho zobrazuje aj v situácii, ked' je opásaný ovčím rúnom a obutý v sandáloch so špinavými šnúrkami. O takom dokonalom rečníkovi nebude l'ahké povedat' niečo znevažujúce ani pochvalné."

Už Dittmar si všimol, že v tomto zlomku vystupuje Télauges ako prívrženec takzvaných pytagoristov, teda tých nasledovníkov Pytagora, ktorí dodržiavali rituálne predpisy - akuzmy - a označovali sa za jeho pravých žiakov (Dittmar 1912, 217). Autori, ktorí upozorňujú na pytagorovské pozadie Aischinovho Télauga, uvádzajú popri Télaugovi ako d’alšieho predstavitel'a takéhoto spôsobu života Diodóra z Aspendu, ktorý má pre zmenu blízko k sokratovskej škole kynizmu (porov. Burkert 1972, 203 - 204; Lampe 2015, 67 - 68; Škvrnda 2016, 98 - 102). Hlavným znakom pytagoristov bol príklon k mysticizmu a rituálnemu životu, založenom na „očist'ovaní“ duše, teda na prísnej askéze. Ich životný štýl sa musel javit' z dobového pohl'adu extravagantne, pričom táto skutočnost' bola vel'mi pravdepodobne reflektovaná aj samým Aischinom, ktorý Télauga zosmiešňuje práve pre jeho schmutzige askese.

Niektorí moderní bádatelia vidia v Aischinovom popise Télauga ako zanedbaného a extravagantne oblečeného filozofa odozvy spartskej paideie obohatenej o akuzmy a typické pytagorovské dogmy, ktorá je predmetom Sokratovej irónie a kritiky (Lampe 2015, 68). Takáto interpretácia obsahu Télauga môže byt' vo svetle nedostatočne zachovaných primárnych zdrojov síce udržatel'ná, no podla nás nie je dostatočne vyargumentovaná. V otázke Sokratovej kritiky a irónie sa totiž odvoláva len na jediný, a k tomu ešte značne nejasný zlomok (Priscian., Instit. grammat. XVIII $189=$ [SSR VI A 88]): „Aischinés v Télaugovi: Užime si teraz, vd'aka tvojej horlivej mysli, niečo dobré. Ja som odpovedal, že aj po smrti Solóna, ktorý uzákonil zákony pre rovných, si práve teraz užívame mnohé dobrá.“

Sokrates údajne celkom v duchu Platónovho neúnavného skúmatel’a podrobuje Télauga kritickému a ironickému rozhovoru, pretože Télauges si chce užit' niečo

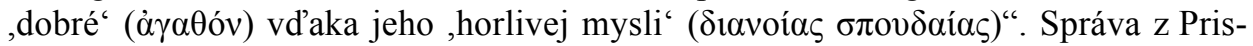
ciana je však natol'ko heslovitá, že nemožno určit' ani adresáta reči, ani jeho hovorcu. Podl'a nás je tento zlomok natol'ko filozoficky irelevantný, že z neho nemožno vyčítat' vôbec nič, čo by súviselo s hlavnou témou dialógu. 
Nazdávame sa, že zlomky z Télauga nevypovedajú o Sokratovej kritike Télauga alebo akuzmatického pytagoreizmu vôbec nič. V skutočnosti to môže byt' skôr naopak: Télauges mohol vystupovat' ako niekto, kto Sokrata svojím životným štýlom z istého hl'adiska prevyšuje, alebo je aspoň rovnako hodný úcty ako on.

Z uvedených zlomkov z Télauga podla nás možno vyčítat' nasledujúce informácie: Aischinés sa cez postavu Télauga vysmieva Kritobulovi za nedostatočnú osobnú hygienu. Télauges žije netradičným spôsobom života, ktorý môže indikovat' pytagorovské pozadie. Zdá sa celkom pravdepodobné, že v skutočnosti ide o Pytagorovho syna a hlavu celej pytagorovskej sekty akuzmatikov. Tomu by nasvedčovala aj skutočnost', že Télauges je zanedbaný nielen $\mathrm{z}$ hl'adiska osobnej hygieny, ale aj oblečenia a vzhl'adu ako takého - ide pravdepodobne o veci, ktoré Télauga vôbec netrápili a zlé svetlo vrhali len na Hermogena. Sokrata napokon privádza do apórie Pytagorova bližšie nešpecifikovaná presvedčivost'. Túto vlastnost' zdedil pravdepodobne aj Télauges, podl'a Herodikovho referátu „dokonalý rečník“, ktorého nemožno ani hanit', ani chválit', pretože jeho telesná zanedbanost' je vyvážená inými vznešenými vlastnost’ami.

Télauges alebo o tom, či sa má filozof vzdat' verejnej činnosti a žit' bez prostriedkov. $\mathrm{O}$ tom, čo $\mathrm{v}$ skutočnosti mohlo byt' hlavnou témou dialógu, vypovedá zlomok z Marka Aurélia (VII $66=[S S R$ VI A 87]): „Odkial' vieme, že Télauges nemal lepšiu povahu ako Sokrates? Ved' tu nepostačuje len fakt, či Sokrates zomrel slávnejší, či obratnejšie diskutoval so sofistami, alebo či otužilejšie znášal noci na studenom snehu...“

Markus Aurélius naznačuje, že Télauges bol rovnako cnostný ako Sokrates, aj ked' v niektorých ohl'adoch bol od neho odlišný - nediskutoval so sofistami, nechodieval na vojenské výpravy a nezomrel po verejnom súdnom procese. To značí, že sa spoločensky neangažoval a žil život v ústraní. O tomto svedčí aj kontext Auréliových úvah o Télaugovi. Pasáži s Télaugom bezprostredne predchádza

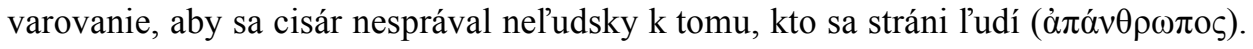
Pasáž, ktorá bezprostredne nasleduje po úvahe o Télaugovi a Sokratovi, zasa spomína, že božím mužom sa človek môže pokojne stat' aj bez toho, že by o tom vedeli druhí, teda bez toho, že by bol známy alebo slávny (Markus Aurélius, VII 65, resp. 67).

Télaugov život „odluda“ tak môže kontrastovat' so Sokratovou filantropiou, ktorú zaznamenáva Platón (Euthyph. 3d) a ktorou bol Sokrates všeobecne známy. Zatial' čo Sokrates horlivo slúžil svojej rodnej obci a druhým l'ud'om, Télauges bol uzavretý do seba a nestaral sa o druhých. Vo svetle nedostatočne zachovaných správ z Aischinovho Télauga môžeme len hypoteticky uvažovat' o tom, aké dôvody mohol mat' Télauges na svoju uzavretost'. Ani v tejto otázke nie sme však celkom bezradní

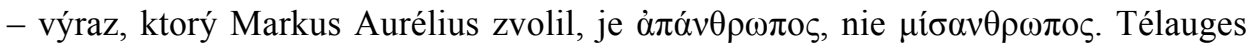
nie je mizantrop, je len „odvrátený“ od l'udí, pretože považuje za dôležitejšie iné veci - starost' o seba je dôležitejšia ako starost' o druhých. Télaugova utiahnutost' 
nachádza svoj predobraz v príbehu o Pytagorovi, ktorý sa na tri roky zatvorí do vyhíbenej jamy a zdržuje sa akéhokol'vek kontaktu s verejnostou. Je to práve táto odlúčenost' od l'udí, ktorá z Pytagora napokon spraví presvedčivého rečníka (Diog. Laert., Vitae VIII 21 a 41). ${ }^{16}$ Okrem toho, Pytagora a Sokrata spája spôsob, akým zomreli - obidvoch zabili rozzúrení spoluobčania, ich „politicki““ protivníci.

Sokratova apória, do ktorej ho dostal Pytagoras, tak môže indikovat', že Télauges reprezentuje iný filozofický postoj k problematike starostlivosti o seba. O tom, ako mohla byt' táto problematika tematizovaná, môžeme uvažovat' opät' len hypoteticky: očist'ovanie vlastnej duše sa má diat' prostredníctvom rituálnych praktík a prísnej askézy, ktoré vylučujú kontakt s „nezasvätenými“ l'ud’mi. V pozadí kontrastu medzi Sokratom a Télaugom môže rezonovat' Aischinova kritika Sokratovej verejnej činnosti, ktorý - ako dokazujú príklady s Alkibiadom, Kritiom, prípadne Aristeidom mladším (porov. Plat., Tht. 150e) - napriek enormnému úsiliu zlyhával pri výchove druhých l'udí. V inom svojom dialógu sa Aischinés pravdepodobne nezdráhal označit' Sokratovu výchovu za dielo lásky, alebo

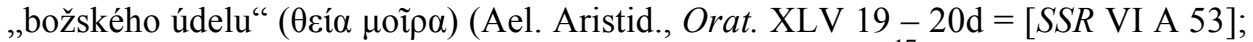
porov. Mársico $(2017,207)$, teda dielo erotického egoizmu ${ }^{17}$ alebo náhody. Mohol Aischinés v Télaugovi naznačovat', že Sokrates bol nezdržanlivý v láske k druhým lud'om a nerozumne sa vystavoval náhode tam, kde mohol mat' veci pod kontrolou?

V zlomkoch Aischinovho Télauga je prítomná vel'ká filozofická téma starostlivosti o seba a o tých druhých. Súčasní autori upozorňujú, že sokratovská starostlivost' o seba sa realizuje dialekticky, teda prostredníctvom starostlivosti o druhých, spoločným hl’adaním definícií a cnostného spôsobu života (Suvák 2016a; 2016b). Po Sokratovom verejnom odsúdení sa však medzi jeho priatel'mi o tejto téme určite viedli kritické diskusie. Mohol Sokrates predíst' hnevu svojich spoluobčanov, ktorý vyústil do obžaloby pred súdom, ak by obmedzil svoju filantropiu len na úzky okruh svojich nasledovatel'ov?

$\mathrm{Na}$ jednej strane sa vyprofilovala skupina sokratovcov, ktorí po jeho smrti žili v ústraní z milodarov vplyvných politikov, či už Dionýzia mladšieho, alebo jeho strýka Dióna (Platón, Aristippos, Aischinés), alebo spartského krála (Xenofón). Na druhej strane stáli Antisthenés a kynici, ktorí zostali v polis, no na rozdiel od Sokrata radikalizovali učitel'ovu filantropiu a radšej si zvolili život v extrémnej chudobe a v špecificky ponímanej láske $\mathrm{k}$ druhým, ktorá je $\mathrm{v}$ skutočnosti ich ostrou a nevyberanou kritikou. ${ }^{18}$

\footnotetext{
${ }^{16}$ Druhá správa z Hermippa pôsobí ako racionalizujúci pokus o vysvetlenie prvej správy, ktorá pochádza od Hieronyma, a ktorá môže siahat' až k Aristippovi. Obidve správy však vidia v Pytagorovom praktizovaní meditatio mortis príčinu jeho nezvyčajnej presvedčivosti.

17 Diskusiu moderných bádatel’ov (najmä Vlastosove úvahy) o povahe Sokratovho egoizmu opisuje štúdia Obdrzalek (2013).

${ }^{18}$ Porov. štúdiu Flachbartová (2014), ktorá tematizuje túto problematiku prostredníctvom vzt’ahu Diogena zo Sinópy k Platónovi.
} 
Ktorú cestu si teda má zvolit' sokratovský filozof, poučený Sokratovým osudom? Aischinova pozícia pravdepodobne nebola čierno-biela. Na jednej strane sa v Télaugovi vysmieval Hermogenovi, ktorý zabúdal na Télauga a neprispieval mu na živobytie. To môže indikovat', že filozof by nemal žit' ako žobrák a úplne zanedbávat' svoje sociálne prostredie. Takisto sa vysmieval z Kritobulovej nevedomosti $(\dot{\alpha} \mu \alpha \theta i ́ \alpha)$, ktorá vzdialene pripomína rozpor medzi Platónovou teoreticky založenou sokratikou a praktickým variantom kynikov, ktorí odmietali učené metafyzické výklady. Na druhej strane podl’a Herodika Aischinés poukazoval na to, že filozofovi nemá až tak záležat' na tom, či ho druhí zanedbávajú, pretože má na starosti dôležitejšie veci ako dbat' o svoje materiálne zabezpečenie. Práve túto amfibóliu môže mat' na mysli aj Demetrios vo svojom spise $O$ výrečnosti (Demetr., De elocut. $291=$ [SSR VI A 89]): „Takmer celé rozprávanie týkajúce sa Télauga vedie $\mathrm{k}$ apórii, či je na výsmech, alebo ho treba obdivovat'. Takáto forma je dvojznačná. Na jednej strane $\mathrm{v}$ nej nie je irónia, no na druhej strane sa tam predsa len odráža niečo ironické.“

Na jednej strane sokratovskému filozofovi nemá primárne záležat' na tom, či mu druhí l'udia budú za jeho dobrodenia prispievat' na živobytie. Keby mu, naopak, na jeho materiálnom zabezpečení predsa len záležalo, jeho život by nemusel stratit' autenticitu, ak by dostával peniaze od iných zaslúžene, teda spravodlivo. Má filozof žit' ako žobrák na posmech ostatným, alebo sa predsa len má usilovat' získavat' prostriedky na živobytie od iných svojou múdrost'ou?

$\mathrm{Na}$ jednej strane vystupuje Sokrates, ktorý žije v rodnom meste všetkým l'ud’om na očiach. Každý deň sa stretáva množstvom l'udí, má dobrého priatel'a Kritóna, ktorý mu všetko zabezpečuje, d’alej Alkibiada a mnohých iných vplyvných známych, ktorí mu prispievajú na živobytie. ${ }^{19} \mathrm{Na}$ druhej strane zasa stojí Télauges, syn slávneho mudrca, ktorého prehliadajú aj vlastní priatelia (alebo Aischinés a sokratovci, ktorí po súdnom procese so Sokratom a demokratickej reštaurácii strácajú príjmy od vplyvných občanov a musia sa uchýlit' za hradby svojho mesta, ak nechcú padnút' na úplné dno spoločnosti ako kynici).

Záver. Meno Télauga sa neskôr objaví aj v istej antickej príručke rétoriky, kde

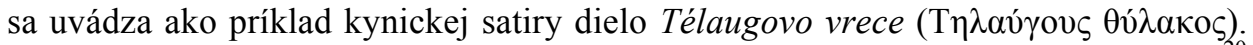
Jej účelom je pobavit' rozumných l'udí (Demetr. de elocut. $170=\left[S S R\right.$ VI A 85]). ${ }^{20}$ Aischinov Télauges tak mohol byt' nielen dialógom s vážnou praktickou otázkou o tom, do akej miery a či vôbec má filozofovi záležat’ na „vonkajších“ dobrách

\footnotetext{
${ }^{19}$ Porov. Diog. Laert., Vitae II 74: Sokratovými pokladníkmi sú poprední Aténčania, ktorí mu posielajú chlieb a víno.

${ }^{20}$ Pozri bližšie štúdiu Cepko (2017), ktorá rekonštruuje filozofické východiská Kratétovej epickej travestie Kapsa. Jej hlavným ciel'om bolo šírit' kynické ideály skromnosti a priatel'skej l'udskosti medzi širšie vrstvy obyvatel'stva. Obsahom Télaugovho vreca tak podobne mohlo byt' šírenie myšlienky dobrovol'ného príspevku (nie nevyhnutne peňažného) na minimálne životné náklady l'ud'om, ktorých by sme dnes asi so všetkou vážnost'ou nazvali bezdomovcami.
} 
a blahu iných. Mohol slúžit' aj ako inšpirácia kynickej satiry, ktorá mieša vážne so smiešnym. Aischinov Télauges svojou dvojznačnost'ou mohol stát' na rozhraní dvoch práve sa rodiacich tradícií sokratiky - kynizmu a platonizmu.

Aischinova sokratika pred nami odhal'uje iný, z dejinno-filozofického hl'adiska dosial' málo akcentovaný horizont: je ním tradícia myslenia, ktorá ešte nerozlišuje medzi sofistami / rečníkmi a filozofmi, ani medzi predsokratovcami a Sokratom. Aischinés ešte nerozvíja metafyzické špekulácie vychádzajúce zo Sokratovej filozofie, ani ju neradikalizuje prísnym asketizmom. Svojho Sokrata stavia pred apórie, problematizuje ho. Usiluje sa z jeho odkazu vyt’ažit' odpovede na závažné praktické dilemy, ktorým čelilo sokratovské hnutie bezprostredne po smrti svojho učitel'a. Jednou z týchto dilem bola pravdepodobne aj otázka, ako sa vyrovnat' so Sokratovou filantropiou a so životom vedeným na cudzie útraty. Jeho filozofická misia, ktorá predpokladala, že starostlivost' o seba sa môže realizovat' len prostredníctvom starostlivosti o druhých, stroskotala zároveň s jeho smrtou.

Aischinovo stanovisko nemuselo byt' vyhranené - nevydal sa cestou k matematickému pytagoreizmu ako Platón, ani smerom k akuzmatickým pytagoristom ako kynici. Platóna upozorňuje, že chudoba a múzická nevzdelanost' nie sú pravej cnosti na prekážku; kynikom sa zase vysmieva za nevyberané správanie, ktoré ich privádza $\mathrm{v}$ očiach druhých do nedôstojného postavenia hraničiacehos opovrhnutím. Aischinés tak stojí kdesi na pomedzí týchto rodiacich sa tradícií sokratovského myslenia a možno práve preto si ho história zapamätá ako najvernejšieho Sokratovho nasledovníka.

\section{Literatúra}

BEALL, E. F. (2001): Diogenes Laertius on Aeschines the Socratic's Works. Hermes, 129 (1), 142 $-144$.

BRISSON, L. (2018): Plato and the Socratics. In: Stavru, A. - Moore, CH. (eds.): Socrates and the Socratic Dialogue. Leiden: Brill, 237 - 266.

BURKERT, W. (1972): Lore and Science in Ancient Pythagoreism. Cambridge: Harvard University Press.

CEPKO, J. (2017): Kratétova kynická utópia. Filozofia, 72 (2), 92 - 102.

DITTMAR, H. (1912): Aeschines von Sphettos. Berlin: Wiedmannsche Buchhandlung.

FLACHBARTOVÁ, L. (2014): Diogenes of Sinope as Socrates mainomenos. In: Suvák, V. (ed.): Antisthenica Cynica Socratica. Praha: OIKOYMENH, 308 - 350.

GIANNANTONI, G. (1990): Socratis et Socraticorum Reliquiae II. Napoli: Bibliopolis.

KALAŠ, A., SUVÁK, V. (2013): Antisthenis fragmenta. Bratislava: Univerzita Komenského $\mathrm{v}$ Bratislave.

LAMPE, K. (2015): Rethinking Aeschines of Sphettus. In: Zilioli, U. (ed.): From the Socratics to the Socratic Schools. New York: Taylor \& Francis, $61-81$.

LAMPE, K. (2010): Socratic Therapy from Aeschines of Sphettus to Lacan. Classical Antiquity, $29(2), 181-221$.

MÁRSICO, C. (2018): Shock, Erotics, Plagiarism, and Fraud: Aspects of Aeschines' of Sphettus 
Philosophy. In: Stavru, A. - Moore, CH. (eds.): Socrates and the Socratic Dialogue. Leiden: Brill, $202-220$.

NAILS, D. (2002): The People of Plato. Indianapolis: Hackett Publishing Company, Inc.

OBDRZALEK, S. (2013): Socrates on Love. In: Bussanich, J. - Smith, N. D. (eds.): The Bloomsbury Companion to Socrates. London: Bloomsbury Academic, 210 - 232.

PENTASSUGLIO, F. (2017): Eschine di Sfetto: alcue nuove testimonianze. Méthexis, 29 (1), 59 88.

PRIOR, W. J. (2013): Socratic Metaphysics. In: Bussanich, J. - Smith, N. D. (eds.): The Bloomsbury Companion to Socrates. London: Bloomsbury Academic, 68 - 93.

ROWETT, C. (2014): The Pythagorean society and politics. In: Huffman, C. (ed.): A History of Pythagoreanism. Cambridge: Cambridge University Press, $112-130$.

SUVÁK, V. (2018): Socratic Therapy as Taking Care of the Self and Others. In: Suvák, V. (ed.): Care of the Self. Ancient Problematizations of Life and Contemporary Thought. Leiden Boston: Brill Rodopi, $1-49$.

SUVÁK, V. (2006): Sókratés a sokratika. In: Suvák, V. (ed.): Sokratika I. Sókratovská tradicia myslenia od antiky po súčasnost'. Prešov: Filozofická fakulta Prešovskej univerzity, 5 - 32.

SUVÁK, V. (2016a): Sókratovská therapeia: Antisthenés o rozumnosti. Filozofia, 71 (2), 85 - 95.

SUVÁK, V. (2016b): Sókratovská therapeia: Platónov Charmidés 153a - 158d. Filozofia, 71 (5), $357-368$.

ŠKVRNDA, F. (2016): Bol Antisthenés pýthagorovec? Filozofia, 71 (2), 96 - 106.

THOM, J. C. (2013): The Pythagorean Akousmata and Early Pythagoreanism. In: Cornelli, G. McKirahan, R. - Macris, C. (eds.): On Pythagoreanism. Berlin: Walter de Gruyter, 77 - 102.

Tento príspevok vznikol ako súčast' riešenia grantového projektu VEGA 1/0017/17 Aischinés a sokratovský dialóg.

František Škvrnda ml.

Katedra medzinárodných politických vzt'ahov

Fakulta medzinárodných vzt’ahov

Ekonomická univerzita v Bratislave

Dolnozemská cesta 1

85235 Bratislava 5

Slovenská republika

e-mail: frantisek.skvrnda2@euba.sk 